\title{
In search of image manipulation mechanisms in a public person's speech interpretation - a case study
}

\begin{abstract}
Summary
This paper presents a qualitative analysis of a public person's speech with its language and translation, and the way they can be manipulated to create a public image. As a public person, Lech Wałęsa has been subject to public scrutiny politically and ideologically ever since he became involved in public affairs as a trade union member and activist. Later, as a presidential candidate in the first democratic presidential election in post-communist Poland which he won in 1990, his publicity soared. Consequently, with his popularity came a heavier price of fame; he was subjected to strong criticism, and the way he spoke became a source of jokes and mocking nationwide. Public image is what others receive and read us by. It is an amalgamation of several factors - language being one of the major ones in creating one's identity.
\end{abstract}

Keywords: identity, ideology, image, language, manipulation, perception, politics, public person, translation

\section{Introduction}

Among the many images everyone has, the public one is among those which people nourish the most, as this image is what others receive and read us by. Whether we are self-conscious about our public image or accept it for what it is its effect is an amalgamation of several factors - language being one of them, and the most affective one at that. Language is an essential tool which hugely facilitates the creation of one's identity or even identities. As Bralczyk claims (1990: 60) '[a] person exists to a large extent through language. A public person exists through their public language'. Although Bralczyk himself did not offer any delineation of what he meant by 'a public person', for the purposes of this paper the label shall broadly refer to any person who exists in the public domain or is otherwise engaged in public matters.

In this paper, we shall analyse qualitatively a specific instance of public person's language as utilised in a public speech event. As a public person, Lech Wałęsa has been subjected to public scrutiny politically and ideologically ever

1 https://orcid.org/0000-0002-2172-4791. 
since he became involved in public affairs as a trade union member and activist. Later, as a presidential candidate in the first democratic presidential election in post-communist Poland which he won and became President in 1990, his publicity soared. Consequently, with his popularity came a heavier price of fame; he was subjected to strong criticism, and the way he spoke became a source of jokes and mocking nationwide.

Lech Wałęsa is supposedly one of the most controversial politicians in Poland and it seems impossible to find an adult Pole who does not know who Wałęsa is. His Political fame and achievements aside, he attracts both eager praise and harsh criticism in his homeland; even more so recently. As a public person, his speech may make him appear uneducated. A simple electrician at Gdansk Shipyard, he was the third person in history at the time who did not hold any important state position to be invited to speak before the joint Houses of the Congress. So far, not many have been granted such an honour.

The analysis in this paper is based on early Wałęsa's language taken from his speech in the American Congress on 15 November 1989, i.e. after the political transition in Poland, but before he became President. Wałęsa's political skills developed over time as his political career unfolded, as did his language and performance on the political stage. His language and the way he used it facilitated the way he was perceived at home. The study here will also look at the language mechanisms at play during his speech before the joint Houses of the US Congress and its consecutive translation into English.

\section{Speech Analysis}

This section presents an analysis of the language of Wałęsa's speech. The Polish quotes used here are accompanied by the official translation delivered at the actual event (included in round parentheses) and an English gloss to illustrate how the actual delivery sounded in square parentheses. It should also be noted that the aim of the analysis is far from offering a judgement or assessment of Wałęsa as a person. The purpose is merely to make a case for the assumption that the way we use language facilitates the way we are perceived by our listeners. This, in turn, can make grounds for manipulation in translation, and can yield specific results. Such manipulation may occur inadvertently, as often happens in interpreting where a speech is smoothed out by the interpreter in the target language for linguistic delivery of the speaker, allegedly so for communicative reasons. However, in fitting circumstances, the strategy to make the target language message more fluent may be a premeditated tactic aimed to achieve certain goals. The problem of ethics and 
loyalties seems inevitable in such cases (as illustrated by Baker 2006 et al), but it remains outside the scope of this paper.

Bralczyk (1990) draws an insightful analysis of Wałęsa's language, which provides grounds for the analysis of Wałęsa's Congress speech in several aspects. It should be noted that Wałęsa's language changed over time and the investigation here concerns only a fragment of his overall linguistic performance during his political career, and only in its early days. The speech was delivered before the joint Houses of the Congress of the US; it takes nearly 55 minutes and is intermittently interjected with long thunders of applause, often lasting approximately 2 minutes each. The speech itself was written by Kazimierz Dziewanowski - the first ambassador in Washington representing the newly free Poland, and the person reading it out in Congress was Jacek Kalabiński, a contemporary US correspondent for The Gazeta Wyborcza [The Electoral Gazette].

Public speaking is generally characterised by smooth and fluent delivery, with words carefully selected and painstakingly put together to create a desired meaning. Therefore, many such speeches may sound artificial, unnatural, fake and emotionless. Public language has become routinised and institutionalised; it represents artificial entities and concepts such as the state, the administration, courts, governments, even schools, etc. Words, phrases and syntax patterns are preferred over others to promote uniformity and a sense of security and trust in the constant nature of the relevant institutions using that language, which often seems stative. Communicating in this way means subscribing to the identity which is fostered through such language. As argued elsewhere, language is a strong indicator of identity, whereas identity reflects a set of beliefs expressed through language (Janczyło 2015). Therefore, by effectively using language, we become part of the community which represents a given cultural capital expressed through the language.

Evidently, Wałęsa's way of speaking was different to that of other trained and experienced public persons of the era. His lack of linguistic aptitude and eloquence introduced a new dimension in the sphere of public speaking. However, he did not shy away from his way of speaking. On the contrary, he seems to have made it one of his major attributes and a beacon to be recognised by. Even his speech before the US Congress contains numerous breaches of the public speaking norms. Even though his speech was prepared and written down to be read out, Wałęsa did not fail to introduce several of his natural linguistic features. For clarity purposes, they are classified into three major kinds in this paper: mispronunciations/misreadings refer to Wałęsa adding or changing sounds within words. Some of them were self-corrected, and some were not. The second group, 
grammatical errors in noun case endings or noun-verb agreement, goes deeper into the Polish syntax and illustrates the complexity which may confuse many Polish speakers apart from Wałęsa. The third and last category contains distorted idioms and metaphors, where Wałęsa shifts from the standard phraseology of certain Polish idioms, metaphors and collocations replacing some words with nonstandard ones or even semantically incorrect.

\subsection{Mispronunciations/misreadings}

In the Congress speech, Wałęsa misreads and mispronounces several words. He inserts different vowel sounds than intended, suspends his voice mid-word and also displays a slight stutter on several occasions. He self-corrects some of his mispronunciations, e.g.:

- 'cudziem... cudzoziemiec'

(foreign non-head)

[foreign... foreigner]

- 'Przeciw przywilejom i mo... monopolowi'

(Against privilege and monopoly)

[Against privilege and mono... monopoly]

- 'Przypa... przypominające Abrahama Lincolna'

(reminiscent of Abraham Lincoln)

[remind... reminds Abraham Lincoln]

- 'Miałosz, miało [...] to'

(It had)

[It has... had]

- 'odz... odzywały się głosy ostrzegające nas, pouczające, a nawet potępiające' (many warnings, admonitions, and even condemnations were reaching us) [voices were... were heard which warned, admonished, and even condemned us]

- 'nie wszędzie zmiany przebie... przebiegają w sposób równie pokojowy' (changes elsewhere are not so peaceful)

[not everywhere are changes as... as peaceful]

- 'nie zdo... zdołały się dotąd na' (have not yet brought themselves to carry out) [have not... have not yet managed to]

- 'dalekosięż... siężne i wszechstronne reformy' (long-ranging and comprehensive reforms) [far... far-reaching and comprehensive reforms]

- 'Michała... Michaiła Gorbaczowa' 
(Mikhail Gorbachev)

[Michael... Mikhail Gorbachev]

- 'do o... europejskiego pojednania

(to a European reconciliation)

[to an... a European reconciliation]

- 'umo... umocnienia praw człowieka'

(strengthening of human rights)

[streng... strengthening human rights]

- 'do odbudowy zni... zniszczonego kraju'

(to rebuilding their devastated country)

[to rebuilding the des... destroyed country]

- 'Stalin zakazał Polskę... -sce'

(Stalin forbade Poland to)

[Stalin forbade that... forbade Poland to]

- 'w za... w zachodniej Europie'

(in western Europe)

[in we... western Europe]

- 'którzy zie... zabierają głos'

(all those commenting on Poland)

[who voi... voice]

- 'długie trwanie obcego na... obcego narodowi systemu'

(Our long subjection to a politcial system incompatible with...)

[long life of the system so alien to the... to the nation]

- 'z... za... z... działanie wbrew'

$(-)$ omitted

[for... at... for... acting against]

- 'rząd wyło... wyłoniony przez

(government elected by)

[government ele... elected by]

- 'polską de... dolegliwością'

(Polish predicament)

[Polish pro... predicament]

- 'doty... dotychczasowe wysiłki'

(past efforts)

[efforts so... so far]

- 'przełamać is... istniejące w Europie podziały'

(patch up the divisions existing in Europe)

[overcome the divisions exist... existing in Europe]. 
Several other mispronunciations were left uncorrected, e.g.:

- 'przypominamć', which was meant to be 'przypominać' [remind]

- 'torują powoli drogę historyczną przemianą [pave the way with a historical transformation], which was meant to be 'torują drogę historycznym przemianom' [pave the way for historic transformations]

- 'trzeba to widzieć' [it is necessary to know], which was meant to be 'trzeba to wiedzieć [it is necessary to know]

- 'nikt nie jest również jak my zainteresowany' [nobody is also like us interested in], which was meant to be 'nikt nie jest równie jak my zainteresowany' [nobody is equally like interested in]

- 'Polska wznosi dziś ważny wkład' [Poland raises today an important contribution], which was meant to be 'Polska wnosi dzis ważny wkład' [Poland is making today an important contribution].

I have counted at least twenty-three instances when Wałęsa's pronunciation collapsed upon the text of his speech. It seems that the difficulty faced by the speaker may have arisen from two sources. Many of the words were long and sophisticated with which Wałęsa perhaps had not had too much experience due to his educational and professional background.

Secondly, the discourse mode (Hatim and Mason 1990) of the speech seems slightly more complex than simply written to be spoken. Wałęsa delivered a speech which was prepared in writing and meant to be spoken, yet generally the speech was mostly read out rather than recited, which was reflected in Wałęsa's generally monotonous tone and artificially rising intonation after most clauses and parts of sentences where a pause, comma or rhetorical stop were used. Moreover, being strongly tied to the written text and having to follow carefully the text of the speech on paper, Wałęsa skipped over several words and phrases. This may have been a result of his assuming that he knew what was written and made him read less cautiously, which resulted in several words being misread, mispronounced or changed. This, together with Wałęsa's employing, whether consciously or not, heavy regional phonetic dialectisms in his speech points to his inexperience in public speaking.

\subsection{Grammatical errors in noun case endings or noun-verb agreement}

In this group, the mistakes which Wałęsa are syntax-based and relate to wrong grammatical gender and/or case suffixes placed on certain nouns, verbs and adjectives:

- 'ostatnio wkroczyli na nią również wschodnie Niemcy' [recently also east Germany/Germans have taken the path] illustrates a complex verb-noun agreement system in the Polish language. 
The word 'Niemcy' has two separate denotations in Polish. In its nominative case it may refer to the country of Germany [Niemcy], and secondly, it may also refer to the people of German origins [Niemcy]. Both words carry different gender and declension weights. Wałęsa's grammatical confusion in the phrase above treats the word 'Niemcy' in both ways at the same time. The finite verb form that 'Niemcy' is the subject of takes a masculine plural suffix giving its subject the meaning of the people who live in Germany. On the other hand, the accompanying adjective in this subject noun phrase [wschodnie Niemcy] displays a feminine/neuter plural suffix '-e', which suggests that the noun 'Niemcy' is used as the name of the country. The correct sentence would employ the finite verb and the adjective in either with a masculine plural suffix '-i' to denote Germans (the people), i.e.:

- 'ostatnio wkroczyli na nią również wschodni Niemcy' [recently also east Germans have followed the path]

or feminine/neuter plural suffixes '-ły' and '-e' for the verb and adjective:

- 'ostatnio wkroczyły na nią również wschodnie Niemcy' [recently also east Germany has followed the path]

- 'zostały jej narzucony nieznany polskiej tradycjom, nieakceptowany przez naród: obcy system rządów, obcy sposób gospodarowania, obce prawa, obca filozofia stosunków społecznych' [there was imposed on Poland, unknown in Polish traditions, not accepted by the nation: an alien government system, alien economy, alien laws, alien philosophy of social relations].

The Polish phrase displays Wałęsa's grammatical inconsistency in applying correct singular or plural suffixes, which are conditioned by the way one looks at the form of the list that follows the colon. The list can be consistently treated in two ways in Polish. Firstly, as it contains a series of entities it can be taken as a plural set and therefore preceded by the finite verb 'zostały' [became] in the plural form and followed by the adjectives 'narzucone' [imposed], 'nieznane' [unknown], 'nieakceptowane' [not accepted] in the nominative plural feminine/neuter case form.

Secondly, the same list can be treated as a single whole and thus will require the finite verb in the singular masculine form 'został' [became] followed by the adjectives in the nominative singular masculine case: 'narzucony' [imposed], 'nieznany' [unknown], 'nieakceptowany' [not accvepted], with the masculine case form in agreement with the nominative masculine case of the first entity in the list, 'obcy system' [an alien system].

- 'wierny mu ludzie' [people faithful to it] displays a lack of number agreement between the adjective 'wierny' [faithful] and 'the noun 'ludzie' 
[people]. The correct phrase should read 'wierni mu ludzie' [people faithful to it], with the suffix ' $i$ ' in 'wierni' indicating agreement with the nominative plural masculine case of the noun 'ludzie' [people] which the adjective modifies.

- 'którzy utrzymują serdeczne... łączność ze swoją dawną ojczyzną' - plural adjective suffix '-e' - [who maintain a hearty (+ plural adjective suffix) link with their old fatherland], which was meant to be 'którzy utrzymują serdeczną łączność ze swoją dawną ojczyzną' - Polish diacritical singular feminine adjective suffix -ą in the object (accusative) case - [who maintain a hearty (+ singular feminine adjective suffix - ą in the object (accusative) case) link with their old fatherland].

\subsection{Distorted idioms, collocations and metaphors}

Wałęsa's speech is characterised by many linguistic idiomaticity lapses which make his language choices sound awkward, incomplete and mismatched. Several prepositional phrases he used in his speech and idioms, collocations and metaphors flout grammatical, lexical and syntactic norms of the Polish language:

- 'ja też nie kocham się w przemówieniach' (I too am not fond of speeches)

[I'm not in love with speeches either]

This phrase sounds rather spoken in Polish, as in standard Polish you can be in love with a person or a depiction of a person rather than concepts or objects. Although this phrase occurs in colloquial language, the speech in front of the Congress of the USA perhaps is not the best time to use it. This colloquialism was smoothed out in translation.

- 'ludzi mających różne języki' (people speaking different languages) [people having different languages]

In Polish, similarly to English, people do not normally have languages, but speak them. This idiomaticity issue in Polish was also concealed and smoothed out in English making it sound more natural.

- 'druga myśl, która nadchodzi mnie' (another reflection that comes to my mind) [another thought that is approaching me]

This phrase contains the verb 'nadchodzi' [is approaching, approaches] which does not collocate with the noun 'myśl' [thought] in standard Polish. The verb which 
is needed here to make a natural collocation is 'nachodzi' [is coming, comes (across)]. This mistake was corrected in translation.

- 'drogę, jaka już jest poza nami'

(the road behind us)

[the road which is beyond us]

The problem in this phrase is the preposition 'poza' [beyond]. Standard Polish allows here the preposition 'za' [behind] as standard for semantic reasons. This mistake was also corrected in the English translation.

- 'znajdujemy się w tym dziele zrozumienia naszego wschodniego sąsiada' (is viewed with understanding by our Eastern neighbours)

[we find ourselves/are located in the task of understanding our eastern neighbour]

This phrase is an example of a misuse of the words 'znajdujemy się' [we are located/find ourselves] in conjunction with 'dzieło' [task, act, work]. In Polish one does not find oneself in a task or work, not is one located in it. This collocation is unnatural and semantically incorrect. The verbs that collocates with the word 'dzieło' [task] in Polish is, for instance, 'wykonywać' [do, perform] or 'tworzyć' [make, create]. However unnatural Wałęsa's use of language sounds here, the English translation seems to have omitted this mistake and re-expressed the message by utterly changing the meaning of the sentence, as if the two talked about different concepts.

\section{Conclusions}

The Polish speech, although read out from paper, displayed numerous slips of tongue, mispronunciations, misreadings, errors and mistakes. However natural they may seem in a language, they play a part in how the speaker is perceived and received by their listeners. The English translation of the speech analysed in this paper lacked adequate renditions of such technical aspects of speech delivery. The English-speaking audience received a speech which seemed much more fluent, smooth and well delivered.

The mispronunciations in the original were lost in translation giving way to fluent phrases and sentences, uninterrupted by stoppages and stutter. On one or two occasions, Wałęsa's broken phonetic fluency in Polish was removed from the English version, and different linguistic choices were applied. Finally, the regional slant to Wałęsa's pronunciation and intonation also disappeared 
in English with no compensation offered or explanation provided. This gives an effect of a well-expressed and well-delivered speech in English, unlike in Polish. As language is the channel through which a public person is received and perceived, in this instance the way Wałęsa may be perceived in English through the translator is at odds with the Polish speech he actually delivered.

Commonly, speeches which are delivered smoothly and fluently, with lapses reduced to a minimum enjoy a wider reception and are more successful in transferring messages. Talks interjected with frequent mistakes, mispronunciations, self-corrections, and other slips of tongue feel intense as they force the listener to focus more on understanding the actual message, or even checking that they have understood the message as intended. This puts the listener under unnecessary strain, which may, in turn, impede on the overall comprehension of the speech.

Nevertheless, as Wierzbicka (1994) claims, '[1]anguages are the best mirrors of the human mind'. Wałęsa's language is rather simple and far from sophisticated, and thus it carries a simple image of the world deprived of all its social, economic and human complexities. As a result, Wałęsa is able to mobilise people like him and those who believe in freedom and justice like him. The language he employs with its inadequacies and inaccuracies feels unrehearsed, untrained, spontaneous and thus natural, believable and convincing. Many of his mistakes remain not corrected in the Polish version, his ill-formed metaphors and idioms remain unchanged, as if Wałęsa did not much care for how he is going to be received by the listener. There are times, however, when Wałęsa attempts to correct his own language, but into other incorrect forms. Bralczyk (1990) goes on to claim that Wałęsa's grammatical, stylistic and lexical mistakes are not representative of his linguistic ineptness, but rather his linguistic carelessness.

\section{References}

Baker, M. (2006). Translation and Conflict, a Narrative Account. London and New York: Routledge.

Bralczyk, J. (1990). 'O języku Wałęsy'. [In:] Teksty Drugie: teoria literatury, krytyka, interpretacja, $\mathrm{nr}$ 4, 60-81.

Hatim, B. / Mason, I. (1990). Discourse and the Translator. London, New York: Longman.

Janczyło, A. (2015). 'Cultural identity, language and narrative', [In:] Ateneum Philological Forum 1(3)2015: 37-46.

Wierzbicka, A. (1994). 'Cognitive domains and the structure of the lexicon: the case of emotion'. [In:] L.A. Lawrence \& S. A. Gelman (Eds.) Mapping the Mind: Domain specificity in cognition and culture, Cambridge: Cambridge University Press, 431-452. 